\section{Smerter hos barn}

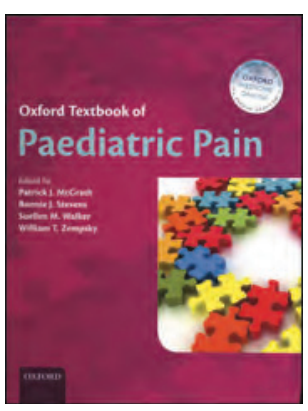

Patrick J. McGrath, Bonnie J. Stevens,

Suellen M. Walker et al, red.

Oxford textbook of paediatric pain

687 s, tab, ill. Oxford: Oxford University Press, 2013. Pris GBP 150

ISBN 978-0-19-964265-6

Oxford textbook of paediatric pain er ment å være standardreferanseverket innenfor emnet smerter hos barn. Målgruppen er alt fra barneleger og anestesileger til allmennleger og psykiatere som jobber med barn. Dette er en omfattende lærebok hvor man tar for seg alle problemstillinger rundt smerter hos barn, fra premature til ungdom. Forfatterne kommer fra mange ulike fagmiljøer i hele verden, med hovedvekt på den engelskspråklige delen.

Kjøper du boken, får du også tilgang til en nettversjon i 12 måneder. Da kan du blant annet søke, lagre søk eller favorittkapitler og laste ned figurer.

De 65 kapitlene er sortert under ni hovedemner. Hvert kapittel er systematisk oppdelt etter samme mal, som ender ut i en oppsummering og vurdering av behov for videre forskning. Illustrasjonene er få, men det er en del tabeller, flytdiagrammer og figurer der det er hensiktsmessig. De kliniske kapitlene er krydret med kasuistikker som er med på å belyse problemstillingen.

Forfatterne begynner med en historisk gjennomgang av smertebehandling hos barn som minner oss om hvor skremmende kort historien for tilstrekkelig smertebehandling og anestesi til barn og spesielt nyfødte/premature er. Boken har en god oversikt over hva som finnes av tidligere litteratur om emnet. Videre følger en gjennomgang av basalforskning på dyremodeller og den nevrofysiologiske bakgrunnen. Forfatterne har lagt mye vekt på den psykososiale delen av det å ha smerter. I de gode kliniske kapitlene tar de for seg spesifikke diagnoser. De dekker også modeller for utvikling av kronisk smerte, tiltak ved smertefulle prosedyrer, måling av smerte, detaljert farmakologi og komplementær behandling, for å nevne noe.

Vanskelige smerteproblemstillinger er blitt vanlig innenfor pediatrien de senere årene. Det er ofte komplekse årsaker som ligger bak, som kan være vanskelige å finne ut av og derfor kan være frustrerende for både pasient, foreldre og lege. Forfatterne tar for seg denne problemstillingen på en veldig bra måte.

Fagfolk i mange ulike spesialiteter vil ha nytte av boken. Den vil kunne fungere som et oppslagsverk, men deler kan også leses sammenhengende for å få en mer helhetlig forståelse av emnet. Verket fremstår som en svært grundig og fullstendig oversikt over smerteproblematikk hos barn og ungdom. Jeg mener derfor at det har en naturlig plass i avdelingsbiblioteket på alle barneavdelinger, anestesiavdelinger og barne- og ungdomspsykiatriske poliklinikker.

\section{Nesten alt man trenger å vite om bein}

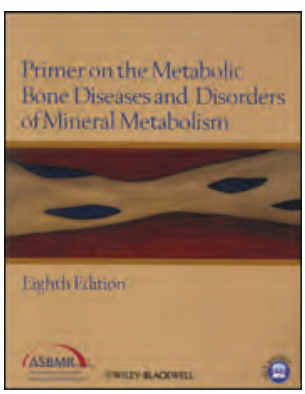

Clifford J. Rosen, red.

Primer on the metabolic bone diseases and disorders of mineral metabolism

8. utg. $1078 \mathrm{~s}$, tab, ill. Chichester:

Wiley-Blackwell, 2013. Pris GBP 87

ISBN 978-1-118-45388-9

Osteoporotiske brudd utgjør et stort folkehelseproblem i mange vestlige land. De alvorligste bruddene er assosiert med økt sykelighet og dødelighet. Norge har verdens høyeste forekomst av underarms- og hoftebrudd. Vi trenger mer kunnskap om skjelettets utvikling fra fosterstadiet, gjennom oppvekst og aldring, for å forstå de drivende kreftene bak bruddrisiko og andre skjelettsykdommer.

Da jeg skrev min doktorgradsavhandling om beinmasse og bruddrisiko i 2005, var den fjerde utgaven av Primer on the metabolic bone diseases and disorders of mineral metabolism til uvurderlig hjelp og støtte. Gjennom en samling av oppdaterte «reviews» på alle aktuelle temaer kunne jeg raskt få tilgang til den oversikten jeg trengte. Siden har jeg fulgt de påfølgende utgavene. Og her er den åttende - i paperback - utvidet med 300 sider slik at den nå til sammen består av 1078 sider fordelt på 11 seksjoner eller kapitler. Mer enn 200 forfattere fra hele verden - alle kjente forskere på sitt felt - har bidratt til de ulike artiklene innenfor hvert kapittel.

Boken starter med en oppdatert kunnskapsgjennomgang av beinbiologi og fysiologi. Osteoporose gis et eget kapittel, det samme gis målemetodene som er tilgjengelige i dag. I tillegg behandles de ulike sykdommene som er knyttet til skjelett-homeostase over flere kapitler. Boken er rettet mot alle som interesserer seg for skjelettets oppbygning, funksjon og dysfunksjon. Jeg vil også tro at alle helsefaglige studenter vil ha stor nytte av boken - med en variasjon av hvilke kapitler og artikler man finner særlig interessante. Selv har jeg med stor interesse lest om osteocyttenes funksjon som mekanosensorer, hva de nyeste studiene sier om effekten av fysisk aktivitet på bein i oppvekst og gjennom aldring, hvilke strategier som virker best for å forebygge fall, og hvilken medikamentell behandling som har best effekt i forhold til å redusere bruddrisiko.

Jeg tror også klinikere i primær- og spesialisthelsetjenesten vil ha stor nytte og glede av de ulike kapitlene og artiklene. Om det er noe jeg savner, er det et eget kapittel om de viktigste sidene ved vurdering av bruddrisiko. En artikkel er viet bruddrisikokalkulatoren FRAX. I andre artikler tar forfatterne for seg ernæring og fysisk aktivitet - jeg skulle gjerne sett dette samlet i neste utgave.

\section{Nina Emaus}

Professor, Det helsevitenskapelige fakultet, Universitetet i Troms $\varnothing-$ Norges arktiske universitet 